\title{
Taming Trojan Horses: Identifying and Mitigating Corporate Social Responsibility Risks
}

Pursey Heugens
Nikolay Dentchev

\begin{abstract}
Organizations are exposed to increasing pressures from their constituents to integrate corporate social responsibility (CSR) principles into their ongoing business practices. But accepting new and potentially open-ended commitments is not a harmless exercise, and companies may well expose themselves to serious risks when embracing such principles. To identify these risks, we conducted two naturalistic studies: one exploratory, the other corroborative. The results show that CSR adoption is associated with at least seven different business risks, ranging from failing strategy implementation to legitimacy destruction. To alleviate these risks, we discuss a set of managerial mitigation strategies that have the potential to realign companies' CSR activities with their strategic objectives.
\end{abstract}

KEY WORDS: corporate social responsibility, corporate social responsibility risks, managerial implications, mitigation strategies, strategy implementation, Trojan horses

Pursey Hengens is an Associate Professor of Organization Theory in the Department of Business-Society Management at RSM Erasmus University. He received his PhD from the same school. His research interests span positive and normative theories of organizaton, including bureaucracy theory, neo-institutional theory, contractualist business ethics, and virtue ethics.

Nikolay Dentchev is an independent research fellow at Ghent University, Belgium, and a project coordinator at the corporate venturing department of Fortis Group (Fortis Venturing). He holds a Ph.D. in business economics from Ghent University. His current research is related to entrepreneurship, instrumental stakeholder theory, and management challenges of corporate social responsibility

\section{Risks without returns?}

The concept of corporate social responsibility (CSR) refers to organizational conduct that proactively integrates the voice of parties affected by business activities in corporate decision-making (e.g. Carroll and Hoy, 1984; Heugens et al., 2002; Hosmer, 1994). This type of conduct typically reaches beyond the firm's economic and legal obligations (Carroll, 1979; McWilliams and Siegel, 2001), in order to satisfy and sometimes exceed its stakeholders' expectations (Clarkson, 1995; Husted, 2000). Of central concern to the socially responsible firm is the potential contribution of its CSR activities to its competitive advantage. From a strategic point of view (cf. Lantos, 2001), CSR involves "the firm's plan to allocate resources in order to achieve longterm social objectives and create competitive advantage" (Husted and Allen, 2000: 25). The strategic lens thus urges us to consider the possibility that investments in CSR activities are deliberately undertaken to enhance the competitiveness of business organizations (Keim, 1978).

Yet, investments in CSR involve relatively irreversible commitments, which can easily backfire in the form of negative effects on the company's competitiveness and competitive positioning (Rugman and Verbeke, 1998). Companies are in especially grave danger when they adopt a low-effort CSRprofile (Stevens et al., 2005), when they do not free up sufficient managerial capacity to manage CSR activities rigorously (Bansal, 2005), or when their investment triggers the interest of previously dormant stakeholder groups (Buysse and Verbeke, 2003). Hence, we portray CSR activities as a Trojan horse that must be tamed by managers before they 
can reap any benefit of their investments. Our main ambition is to systematically identify different types of corporate social responsibility risk, which we define here as any unintended pressure on a firm that occurs as a side-effect to its acceptance of social obligations beyond its legal and economic responsibilities.

\section{Prior literature on CSR risks}

The CSR literature generally favors corporate engagement in CSR activities. Many CSR scholars point out that companies can have a significant impact on alarming social and environmental developments (Starik and Marcus, 2000). Indicative are the numerous discussions by CSR scholars of corporate scandals (such as Enron, WorldCom, and Parmalat) and environmental disasters (such as Chernobyl, Bhopal, and Exxon Valdez). In addition, contested industries (such as alcohol, gambling, tobacco, chemicals, petroleum, and nuclear energy) and morally questionable activities (such as bribery, child labor, and sexual or racial discrimination) are also "usual suspects" in the CSR literature. It has been emphasized that if companies indeed cause harm to people and the natural environment, we should aim to find a solution to this problem. Nobel laureate Ronald Coase (1960) has argued that such solutions can materialize in three alternate ways. The first solution relies on the market mechanism, so that the 'invisible hand' will discipline those causing harm to others. The second solution is oriented toward the reorganization of business activities in a way that internalizes the problem, so that the existence of unpriced negative externalities will be minimized. A third solution may be provided by the government, through regulatory action aimed at the prevention or minimization of harmful activities.

In spite of this relatively broad range of alternatives, the CSR literature tends to focus on only one of these solutions, i.e. the reorganization of business activities to the point where companies will promote 'social good' and prevent 'social harm' (Fitch, 1976; Wells, 1998). The market and government solutions were regarded as inferior from the very beginning of CSR theorizing. The CSR literature emerged as a criticism of the neoclassical theory of economic growth (Wartick and Cochran, 1985), which postulates that companies should maximize their profits
(Friedman, 1970). This neoclassical contention is indeed based on the presumption that market forces and governments (as a last resort) will address harmful activities. But the CSR idea opposes this contention from the perspective that harmful business activities are still regularly observed in capitalist markets regulated by democratically elected governments. Another often-used argument is the dramatically increased power of multinational companies, which possibly aligns corporate preferences with the law through corruption and lobbying (e.g. Hertz, 2001). Overall, the CSR literature advocates the reorganization of corporate activities as the most appropriate solution to alarming social and environmental developments. Moreover, companies are urged to invest in CSR activities permanently, and not only when they cause harm.

The preference of CSR scholars for businessdriven solutions to the problem of social cost (Coase, 1960) helps us understand CSR's resonance with the corporate world. However, too little attention has been paid to the managerial consequences and especially the negative organizational effects of embracing CSR principles (Dentchev, 2004). Although the relationship between corporate social performance (CSP) and corporate financial performance (CFP) is extensively studied in the CSR field (e.g. Margolis and Walsh, 2001, 2003), it remains rather elusive as some studies report a positive relationship, while others report no relationship, and still others report a negative relationship. In retrospect, Margolis and Walsh (2003) argue that the search for a positive CSP - CFP link is an attempt to show the superiority of CSR theory compared to its rival theory, the neoclassical theory of economic growth. Attempts along these lines can explain the limited attention paid to CSR risks.

There are at least three prior indications in the literature that provide endorsement for the project of CSR risk identification. First, the potential for negative effects of CSR adoption on firm competitiveness is occasionally referenced in the argumentation for research hypotheses (e.g. Margolis and Walsh, 2001; Waddock and Graves, 1997). Second, these negative effects may have a theoretical explanation. Keim (1978) describes CSR activities as 'investments' in a public good. This means that while one party allocates resources, everyone (competitors included) can enjoy the benefits of 
improved public services. Third, prior empirical studies appear to suggest the existence of CSR risks. Bowman and Haire (1975) found an inversedU-relationship between corporate social performance and financial performance. More recently, Husted and Allen (2004) found a negative relationship between one widely accepted CSR characteristic (volunteerism) and the value creation of firms.

A more systematic assessment of CSR risks thus seems appropriate. We thus conducted two naturalistic studies (Lincoln and Guba, 1985) to capture the broadest possible variety of risks. The first is an exploratory study that enabled us to identify seven CSR risks. To cast our nets as widely as possible, we interviewed 18 European experts with quite varied stances on CSR. This research strategy is consistent with received views in strategic management that individuals are likely to interpret issues from the standpoint of their own interests (Dutton and Webster, 1988), prior experiences (Daft and Weick, 1984), and functional level in the organization (Heugens, 2005). We then designed a second, corroborative study to test whether these findings would also hold in a corporate setting. This study involves the case of the CSR policy and performance of one of the largest petrochemical companies worldwide.

\section{Study 1: Experts}

\section{Method}

For the first study we employed the grounded theory method (Glaser and Strauss, 1967) to uncover various CSR risks. Grounded theory is a research method that allows much flexibility when collecting and interpreting the data. Consequentially, when using this method the researcher must "specify quite explicitly upon what kinds of data his interpretation rests" (Glaser and Strauss, 1967: 233). Specifically, we used interviews with 18 European CSR experts as our primary source of data (see Table I). We selected experts primarily on the basis of their knowledge of and experience with CSR.

The sampling logic we followed was that of the most different systems design (Przeworski and Teune, 1970), including respondents with widely different institutional affiliations - e.g., academic institutions, business networks, NGOs, and labor unions. We asked these respondents what dangers they foresaw for companies seeking involvement with CSR. We took detailed notes during the interviews, and we wrote detailed interview reports immediately after each research conversation. As indicated before each interview, we sent our informants an electronic version of the interview report by e-mail, usually within a week, and asked them to review these notes. This typically resulted in a few minor corrections per interview, which increased the accuracy of our observations.

Results

Seven risks associated with CSR investments were identified. Four of these risks - diluting managerial attention, non-productive spending, stretching the organizational coalition, and bad strategy implementation - play out at the organizational level of analysis (see Figure 1). They (a) refer to organizational insiders, and their impact is (b) most likely to be felt inside the organization, (c) more likely to be substantive than symbolic, and (d) prone to influencing internal coordination and governance mechanisms. In contrast, the remaining three risks legitimacy destruction, issue ownership, and poor risk communication - are located at the interorganizational level of analysis (see Figure 1). The latter (a) primarily refer to persons and groups that are outside the (dominant) organizational coalition, and their impact is (b) most likely to be felt in the interorganizational networks in which the company participates, (c) more likely to be symbolic than substantive, and (d) prone to influencing the organization's externally construed legitimacy, reputational standing, and social capital. Both groups of CSR risks are likely interrelated, however, as problems in the organizational management of CSR activities can provide negative signals to internal as well as external stakeholders. We proceed with a brief discussion of these seven risks.

\section{Diluting managerial attention}

In an interview with the network coordinator of Trivisi, a foundation sponsored by the Flemish government to stimulate the adoption of CSR practices, the following concern was raised: 


\section{TABLE I}

Expert Interviewees

\begin{tabular}{lll}
\hline$\#$ & \multicolumn{1}{c}{ Organization } & \multicolumn{1}{c}{ Function } \\
\hline 1 & Trivisi & Network coordinator \\
2 & ABVV (Labor-union) & Head of education department \\
3 & Ghent University & Professor of sustainable development \\
4 & Koning Boudewijnstichting & Network coordinator \\
5 & Flanders Network for Business Ethics & Network coordinator \\
6 & Ghent University & Associate professor in environmental economics \\
7 & Ghent University & Assistant professor in environmental economics \\
8 & Catholic University of Louvain & Professor of sustainable development \\
9 & Vlerick Leuven Ghent & Senior research assistant in corporate \\
& Management School & social performance \\
10 & Catholic University of Louvain & Professor of business ethics \\
11 & Kauri & Network coordinator \\
12 & Greenpeace (NGO) & Executive director \\
13 & Vlerick Leuven Ghent & Senior research assistant in corporate \\
& Management School & social performance \\
14 & Business and Society Belgium & Network coordinator \\
15 & Ethibel (Consultancy bureau & Executive director \\
& for ethical investment) & \\
16 & UNIZO (Syndicate of entrepreneurs) & Head of education department \\
17 & Antwerp University & Full professor in sustainable development \\
18 & Bond Beter Leefmilieu & Integral product policy advisor \\
& (umbrella of environmentalist & \\
& organizations) & \\
\hline
\end{tabular}

E1: ${ }^{1}$ To embrace the principles of CSR implies that firms not only acknowledge and embrace economic and financial values, but also social, societal, and environmental values. What really matters is that one at least acknowledges all stakeholders that operate in and around the

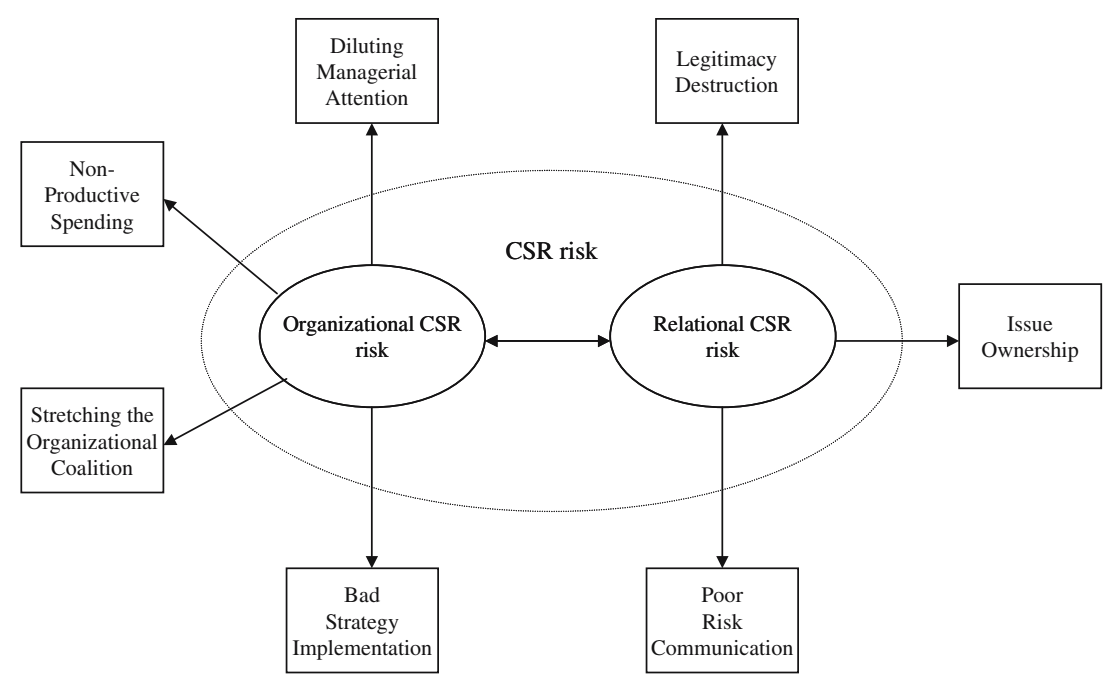

Figure 1. A grounded conceptualization of CSR risk. 
firm. (...) But the primary reason of being in business is to turn a profit. The real danger of CSR is that one loses sight of the commercial strategy. It is perfectly conceivable that an enthusiastic firm begins to orient itself primarily to the pursuit of social and ecological goals, even if economical aspects are its primary purpose.

From a managerial portfolio perspective, CSR represents a novel activity that demands managerial attention and that siphons off scarce managerial resources from the company's core productive activities. We therefore suggest:

Proposition 1: The adoption of CSR activities involves the risk of spreading managerial resources too thin over a larger number of investment alternatives.

\section{Non-productive spending}

In an interview with a Senior Research Assistant active in CSR at Vlerick Management School (Belgium's leading business school), the following concern was raised:

E9: To us, the definition of CSR is closely related to stakeholder management (...) In our view, the most important aspect of running a business is to define and implement the corporate strategy, and this is a matter of anticipating and responding to stakeholder behavior (...) But in the CSR field, a thousand-and-one definitions, terms, and interpretations exist as to what CSR is and ought to be. When firms do not get a clear signal about the true nature of CSR, about what firms must do to live up to its principles, and how one can reach a more responsible steady state of operations (...) investments in CSR amount to nothing but costs, reputational risks, and wasted time. (...) If you take the socalled Triple Bottom Line as an example, in which not one but three ultimate goals are suggested for the firm, such an exercise is bound to generate internal tensions. Tensions that weren't there before, and that cannot be resolved.
The issue at stake is that CSR activities are at least partially investments in public goods (Keim, 1978). While no one can deny the value of, say, cleaner air or societal stability, the production of these goods tends to go hand-in-hand with problems of collective action. Any company making significant investments in such goods without gaining and enforcing the commitment of relevant competitors is likely to suffer in factor, capital, and product markets (Friedman, 1970; Jensen, 2001). Hence we propose:

Proposition 2: The adoption of CSR activities involves the risk of spending resources unproductively on goals that encourage free-riding behavior in stakeholders.

\section{Stretching the organizational coalition}

The following threat of CSR implementation was raised in an interview with another Senior Research Assistant active in CSR at Vlerick:

E13: The CSR approach is laden with normative assumptions and prescriptions. Yet these are not all innocent or harmless. CSR principles state that firms must integrate the interests of their stakeholders into the day-to-day decisions that they make. Not just those of the most powerful stakeholders, but also those of parties that are merely influenced by the enterprise (...) But I foresee great danger for any enterprise that allows its business policy to be dictated by its external constituents. This "management by stakeholders" entails such a democratic concept of governance that it can easily lead to total anarchy.

The behavioral theory of the firm holds that organizations can be perceived of as a "coalition" involving many dissimilarly interested parties (Cyert and March, 1963). One of the foremost challenges facing organizations is providing these parties with adequate inducements to safeguard their contributions. By engaging in CSR practices, firms effectively broaden the scope of their coalition. This puts greater pressure on the organization to provide the appropriate incentives (cf. Prahalad and Bettis, 1986, 
1995), and one of the unwanted consequences of CSR might be that primary stakeholders, like buyers and suppliers, lose interest in the firm if it no longer serves their basic needs. Therefore, we argue:

Proposition 3: The adoption of CSR activities involves the risk of broadening an organization's coalition beyond a feasible set.

\section{Bad strategy implementation}

When we asked one of the associate professors at Ghent University about the potential risks of CSR, we received the following response:

R6: The successful implementation of ongoing continuous improvement trajectories in the area of environmental management, or in the broader area of quality control, can become obstructed if we have to wait for the new concept to crystallize (...) One of the most important factors holding back the successful implementation of CSR activities is the lack of usable performance indicators (...) we simply have no good measures to evaluate the actual infusion of CSR principles in a business. It then becomes a very difficult concept to measure, and on top of that it will become very hard to obtain some degree of consensus concerning the future implementation of the integral CSR concept.

Involvement in CSR activities has almost acquired the status of a new "generic strategy" (Porter, 1980). Organizations presently seek a sustainable competitive advantage by controlling their costs, by differentiating their products from those of competitors, or by adopting a corporate image in which the company as a whole is portrayed as more responsible, aware, and responsive to the needs of a broader group of organizational stakeholders (Heugens et al., 2003). But good strategy selection must be followed up by good strategy implementation (e.g. Bourgeois and Brodwin, 1984). This leads us to the following proposition:

Proposition 4: The adoption of CSR activities increases the risk of bad strategy implementation when pivotal stakeholders are turned off by the difficulties of measuring the successfulness of a CSR-based strategy.

\section{Legitimacy destruction}

We obtained the following response from one of the full professors at Ghent University about possible perils of CSR:

E3: The concept of CSR sails under many colors, and the question is how this diversity manifests itself within the firm. At the very least, we expect some heightened attention to the integration of economic, social, and ecological aspects in the ongoing policies of the firm (...) But dilution and the abuse of the concept lower the credibility of the firm. That is why I favor the verification of CSR reports and communications by third parties; otherwise there is a great risk that such activities will be perceived as attempts at window dressing.

Certain companies are perceived of as being illegitimate by default. Actors in contested industries often find that the adoption of CSR-related activities does not automatically lead to a better corporate reputation or public image (Ashforth and Gibbs, 1990). Instead, CSR investments by companies in, say, the petrochemical, defense, and tobacco industries are often greeted with cynicism, and lead to legitimacy destruction rather than build-up. Thus:

Proposition 5: The adoption of CSR activities increases the risk of lowering organizational legitimacy, because it can easily be mistaken for a signal that the organization has to compensate for some misconduct.

\section{Issue ownership}

When we asked the network coordinator of Kauria Flemish platform supporting sustainable international entrepreneurship - for his opinion on the potential risks of CSR, he gave us a surprisingly candid answer:

E11: Companies must remain companies! They must not try to "save the world," and they must not seek to take over the task of other institutions like government, NGOs, or civil society. They simply must perform the tasks they are supposed to perform responsibly (...) Corporate social responsibility does not mean that management must play every conceivable 
part. Running a company simply means marketing high-quality products (...) One of the great dangers of everything that is being said and written about CSR is that people are beginning to see companies as "mini societies." It seems like other groups are shifting the responsibility for resolving every conceivable issue that bothers them towards corporate actors. But a company is a company, and we may not overstretch our expectations of them.

CSR investments do not occur in a social vacuum, but rather in an embedded setting in which many actors are aware of the decisions made by others. In such settings, a company's involvement with certain social problems or issues is likely to be perceived as an information signal (Dentchev and Heene, 2004) that testifies to that company's responsibilities with respect to the issue. Issue-related investments can thus easily lead to issue ownership. Therefore:

Proposition 6: The adoption of CSR activities heightens the awareness of a firm's audiences of linkages between the firm and certain societal issues, thus increasing the firm's perceived responsibility for resolving such issues.

\section{Poor risk communication}

An assistant professor at Ghent University pointed us in the direction of the following CSR-related risk:

E7: CSR has to be implemented consistently, strategically, with a good communication plan (...) Its essential utility is that, by making investments in CSR activities, the firm can mitigate certain uncertainties that are bound to occur in the future. Prevent confrontations, foresee abrupt changes, handle crises involving stakeholders (...) But to have this effect, CSR must be embedded in adequate corporate communications. The firm can be confronted with diametrically opposed perceptions of what it does effectively and what not, or what goals it should continue to pursue and which it should lay to rest. But CSR always needs an adequate communications campaign; if you fail to communicate with the outside world, CSR will always be perceived as a public relations campaign. To allow the emergence of such misunderstandings means that you will miss out on all longterm opportunities (...) it means that all your sincere efforts will be seen as instrumental, shallow public relations exercises.

A final concern with CSR-activities is that they may stir up latent concerns amongst consumers and citizens. Corporate communication concerning certain issues may well bring issues to the active attention of individuals, where they were only perceived subliminally at first. Furthermore, the association of a company name with certain social or environmental issues, no matter how intelligently or carefully communicated, may stir up a plethora of unwanted side effects. In this context, we formulate the following proposition:

Proposition 7: The adoption of CSR activities can increase the risks outsiders perceive to be exposed to, especially if firms fail to communicate about their motives for adopting CSR practices in ways that cohere with outside audiences.

\section{Study 2 - organization}

\section{Method}

The purpose of the second study was to investigate whether the CSR risks identified in the first had any relevance in a business setting. We therefore adopted the case study methodology (Flyvbjerg, 2004; Gerring, 2004), focusing on the Health, Safety and Environment (HSE) policy and performance (as a proxy for CSR adoption) of a leading multinational firm in the petrochemical industry. Further indicators of the company's commitment to CSR are its: (a) inclusion in indexes like the Dow Jones Sustainable Performance Group, the FTSE4GOOD Indexes, and Fortune Reputation Index; (b) endorsement of the Global Sullivan Principles; (c) membership of CSR Europe; and (d) participation in the CAUX Round Table.

In all, we interviewed 27 respondents over a four-month period. Of these, 22 were employees of the company (with respondents ranging from 
TABLE II

Company interviewees

\begin{tabular}{lll}
\hline$\#$ & \multicolumn{1}{c}{ Level of analysis } & \multicolumn{1}{c}{ Function } \\
\hline 1 & Policy-group level & Executive VP Technology, Portfolio \& \\
& & Sustainable Development \\
2 & Policy-group level & Executive VP Operational Excellence \\
3 & Policy-group level & HSE Strategy and Communication \\
4 & Policy-group level & Issues Manager \\
5 & Execution-group level & Business Development Manager \\
6 & Execution-group level & Sales Manager \\
7 & Execution-group level & Issues Manager \\
8 & Advisory-group level & Sustainable Development coordinator \\
9 & Advisory-group level & Manager new developments logistics \\
10 & Advisory-group level & HSE advisor \\
11 & Policy-operational level & Plant Manager \\
12 & Policy-operational level & Manager Technology \\
13 & Policy-operational level & Manager Health Safety Environment Quality \\
14 & Policy-operational level & Manufacturing Manager \\
15 & Advisory-operational level & Environmental advisor \\
16 & Advisory-operational level & Environmental technologist \\
17 & Advisory-operational level & Factory operations instructor \\
18 & Advisory-operational level & Factory operations instructor \\
19 & Execution-operational level & Operator \\
20 & Execution-operational level & Operator \\
21 & Execution-operational level & Operator \\
22 & Execution-operational level & Operator \\
23 & External stakeholder & Chief Complaints Department, Local Government \\
24 & External stakeholder & Member of the Neighborhood Council \\
25 & External stakeholder & Project manager, Contractor \\
26 & External stakeholder & NGO representative \\
27 & External stakeholder & Sales Manager, Transport Company \\
\hline & &
\end{tabular}

top-management to the shop floor level) and five external stakeholders (see Table II). The face-toface interviews addressed questions about the purpose, organization, and impact on competitiveness (positive or negative) of the company's HSE activities.

We used a number of commonly recommended procedures to ensure the quality of our data work. We aimed to increase the reliability of our findings by carefully documenting our data collection procedures and organizing our interview notes in an NVivo project database (cf. Yin, 1994). As in the first study, we took detailed notes and asked our respondents to verify an e-mailed version. We also used two tactics to ensure the construct validity of this study, i.e. the correspondence between the operational measures in use and the theoretical concepts they are supposed to represent (George and Bennett, 2004): (1) triangulation of data collection methods (interviews, internal documents, and media reports), and (2) verification of the case study report by three employees of the petrochemical company, who judged the accuracy of the data collected, though not its conclusions.

\section{Results}

We analyzed the data gathered in this study against the background of our propositions, finding modest to strong corroborative support for them. We first constructed a 7 by 27 coding matrix by juxtaposing our research propositions and our company 
TABLE III

Coding matrix

\begin{tabular}{|c|c|c|c|c|c|c|c|}
\hline & $\begin{array}{l}\text { 1.Diluting } \\
\text { managerial } \\
\text { attention }\end{array}$ & $\begin{array}{l}\text { 2. Non-productive } \\
\text { spending }\end{array}$ & $\begin{array}{l}\text { 3. Stretching the } \\
\text { organizational } \\
\text { coalition }\end{array}$ & $\begin{array}{l}\text { 4. Bad strategy } \\
\text { implementation }\end{array}$ & $\begin{array}{l}\text { 5. Legitimacy } \\
\text { destruction }\end{array}$ & $\begin{array}{l}\text { 6. Issue } \\
\text { ownership }\end{array}$ & $\begin{array}{l}\text { 7. Poor risk } \\
\text { communication }\end{array}$ \\
\hline 1 & & & & & 2 & & 1 \\
\hline 2 & & & 1 & 1 & 1 & 1 & \\
\hline 3 & 1 & & 2 & 1 & 1 & 1 & \\
\hline 4 & & & & 1 & 2 & & \\
\hline 5 & & & & 1 & 1 & & \\
\hline 6 & & & 1 & 1 & & & \\
\hline 7 & & & & & & 1 & 2 \\
\hline 8 & & & 1 & & & & \\
\hline 9 & & 1 & & & 1 & & 1 \\
\hline 10 & & & 1 & & & 1 & \\
\hline 11 & & & & 1 & 1 & 1 & 1 \\
\hline 12 & & 1 & & & 1 & 1 & \\
\hline 13 & & & & 1 & & 2 & \\
\hline 14 & & & & & 1 & 1 & 1 \\
\hline 15 & & & & 1 & & 1 & 1 \\
\hline 16 & & 1 & & & & 3 & 2 \\
\hline 17 & & & & 2 & & & \\
\hline 18 & 1 & & & 2 & & 1 & 2 \\
\hline 19 & & 1 & & 1 & & & \\
\hline \multicolumn{8}{|l|}{20} \\
\hline 21 & & & & 3 & 1 & & 1 \\
\hline 22 & & 1 & & & & & \\
\hline 23 & & & 1 & & & & 1 \\
\hline 24 & & & & 3 & & 1 & 2 \\
\hline 25 & & 1 & & 4 & & 1 & \\
\hline 26 & & & 1 & 1 & & 2 & \\
\hline 27 & & & & & & 1 & \\
\hline Tot & $2 / 27$ & $6 / 27$ & $7 / 27$ & $15 / 27$ & $10 / 27$ & $15 / 27$ & $11 / 27$ \\
\hline
\end{tabular}

interviewees (see Table III). We then carefully coded each of our interview reports, again using NVivo software, generating an entry into the coding matrix each time a respondent mentioned or described one of the aforementioned CSR risks. Occasionally a respondent reported multiple incidences of a given CSR risk, which were then cumulated in the appropriate cell. Coding matrices like the one presented here are often used in the quasi-statistical approach to qualitative data analysis (cf. Becker and Geer, 1960). Their purpose is to complement the illustrative value of individual respondents' quotes with a systematic representation of the broader patterns in the data.
Diluting managerial attention

We found only a modest degree of support for the idea that CSR activities dilute managerial attention (2 out of 27 interviewees acknowledged the risk), but the examples we did find were quite telling. We asked one of the company's HSE Strategy \& Communication advisors what resources were spent on HSE:

O3: ${ }^{2}$ In short, people and money. We have 200 HSE professionals and 1000 employed in positions that are critical to HSE. This is our internal people resource. (...) The capital investment is on environment and plant 
improvement. (...) Anyway, it is hundreds of millions of dollars. (...) We are prepared to comply with everyone's wishes, but at the end of the day, we have to know what our business is. I dare to say that the expectations of regulators are generally met. But there are stakeholders that deliberately take up such positions that we won't meet their expectations. (...) An NGO like Greenpeace just wants us to improve, but not to meet their expectations. If we tried to meet their standards, we would simply price ourselves out of the market.

Similarly, when we probed one of company's Factory Operations Instructors about how HSE expenditure and overall profitability are balanced, we got the following response:

O18: I have no idea how we actually manage to balance HSE expenditure and overall profitability. Probably they simply have a certain budget for that. When we are building a new plant, it should be as safe as possible, but at the same time affordable. There must be some kind of distribution key.

We: But what would your reaction be if more people were allocated to HSE?

O18: It's OK as long as they don't bother me with questions! [Laughing] No really, I have no idea of how much people they need in that department. My feeling is that they already have a lot of people, and that they should be able to make do with them. These people also have to be managed, and money must still come from production. (...) What I see and hear is that the company is doing well, but we should be careful. My feeling is that we're doing too much on HSE.

We thus find (some) corroborating evidence that CSR activities are seen as a drain on managerial resources, and that more investments would spread managerial attention too thin.
Non-productive spending

Our study yielded moderate support for Proposition 2 , with 6 out of 27 respondents referring to the danger of "wasting" organizational resources on irretrievable CSR investments. Our respondents tended to describe CSR-related spending as "costs" rather than "investments." CSR expenditures indeed have an opportunity cost, in the sense that every dollar spent on CSR cannot be invested in other revenue-generating activities. One of the company's New Development Logistics managers shared his perception of extant resource allocation patterns:

O9: To come back to what I have said, quality has its price. If we wouldn't invest in HSE, we wouldn't sell so many products. (...) We sell because customers regard us as a secure supplier. You have to spend on HSE to be profitable. But you have to be careful, because it costs you money, and spending too much could turn the business unprofitable. You know, it is a progressive exponential function, whereas in the beginning you can achieve much with relatively low investments, but later on you end up spending enormous amounts for just a marginal improvement. And then customers still have to be prepared to buy your product. Customers have their cost limits, and our product should not exceed those.

A related problem is that CSR expenditures can also lead to productivity-destroying organizational routines. Many CSR expenditures crystallize in the form of prescriptive statements such as new organizational rules or standard operating procedures. Unfortunately, these routines often tend to result in higher bureaucratic costs for the organization itself and for many of its stakeholders:

O25: Another example involves a subcontractor of ours, who never wants to work for this company again. A truck driver lost his footing on a piece of surface that had somehow gotten a little slippery. The guy did not even fall, but a safety inspector caught a glance of him rubbing his leg afterwards. Incredible, but the guy was then urged to report to the first-aid worker on duty at that plant, and was 
subsequently taken to the doctor at a small industry town some 15 miles away from the plant. And afterwards they still ran him trough an entire mill of formalities; simply an entire day lost for nothing. This company should simply stop acting as a moral crusader, or we are undoubtedly headed for more clashes with them.

In short, CSR spending tends to come with a number of productivity-diminishing side effects.

Stretching the organizational coalition

We found moderate support for our third proposition, as 7 out of 27 respondents referred to dangers related to an expanded coalition of decision makers. The following example derives from a group-level sales manager:

We: But what is your feeling: have all stakeholder expectations been met?

O6: It's really only my feeling, but I cannot prove it with hard data. Their expectations are broadly met. People have high expectations and I observe that they are generally satisfied. But more than that I cannot say or prove. (...) It is difficult to judge. There are so many segments and sub-segments in society. The demand for information, and the quality of information we provide over the Internet could be good measures to answer this question. (...) Yet I doubt whether any change in our strategy would lead to more positive stakeholder reactions across the board. Given the diversity of stakeholders and of their interests, I would doubt whether we could ever satisfy all of our stakeholders at one time. But if you take the word "all" out of your question, then I would probably say "yes."

Virtually every company has a few "unbridgeable" stakeholders in its stakeholder set (Heugens et al., 2002). These are parties whose interests are so diametrically opposed to those of the focal organization, that the chances that the organization will ever meet their expectations are really quite slim (Heugens and van Oosterhout, 2002). The
Executive Vice President of Operational Excellence illustrated the difficulty of dealing with such parties:

O2: Some stakeholders expect perfect performance, no emissions, or even that we quit our business as to leave no ecological footprint at all. Well, let me tell you that it is extremely hard to have a conversation with that last group of stakeholders. Some stakeholders take up the position that everything we tell is a lie. They will always say: "you tell us one thing, and then do another," and that offers dim possibilities for a constructive conversation. We struggle to bring such parties into the fold, for example by seeking external verification for everything we are saying.

We: How do you manage these difficulties?

O2: Our external affairs people manage them. One part of their job is to engage in a conversation with groups to see where we have a common ground and where we have extremely different views. (...) Occasionally you also have to cope with some unintended consequences. Doing a better job to meet the expectations of one stakeholder might make some matters worse for another. Overinvestment in environmental affairs, for example, might not make shareholders and customers happy.

In sum, when companies seek to add CSR components to their corporate strategy, the core questions they must address are: (a) how can they satisfy the demands of certain stakeholders in the organizational coalition without losing the support of others, and (b) how should they deal with stakeholders whose demands are so contradictory to those of the organization that they categorically refuse to become part of the organizational coalition?

\section{Bad strategy implementation}

Our second study yielded an overwhelming degree of support for the bad strategy implementation view, as no less than 15 out of 27 respondents made unsolicited remarks concerning the risk of losing 
employee support, or of not getting it in the first place. An interview with a Business Development Manager illustrates as much:

O5: Yes, we indeed introduced safety improvements for employees and there was quite some resistance. They thought that those measures were not necessary. Besides, they perceived that wearing that equipment could send a negative signal to customers. We have some work to do on the employee perception.

In an interview with one of the company's Environmental Advisors, a similar concern was raised. Here, we find evidence of an unfortunate mismatch between the (international) organizational policy of a multinational and the national culture in one of its dominant (national) subsidiaries:

O15: Last year we sent to employees 'cards' that they were supposed to give to someone else as an acknowledgement of good HSE behavior. Apparently it was not a good idea, at least for the local mentality. Employees thought it was a joke!

A lack of employee support can easily lead to further problems with strategy implementation. Unfortunately, endorsement problems are magnified at the fringes of the organization. Especially when CSR standards have to be harmonized with outsiders, a lack of support can have negative effects on the organization's ability to realize its objectives. We obtained the following fragment from a Project Manager working for one the company's contractors:

We: Could you make any recommendations to the company to further improve its business practices?

O25: You caught me a little off-guard there. [Hesitates] If I were the company, I would have surveyed the employees of contractors to see whether HSE regulations are really endorsed at the shop floor level. During joint meetings we are all nodding our approvals, but back on the job operational problems tend to suck me up and I simply cannot find the time to talk to my people. (...) We could appoint another safety coordinator, but the company refuses to pay. I believe that the company should demand a markup for safer operations on any contract they sign with subcontractors. It is a tough market, and we are forced to enter competitive bids. We have to undercut our prices to such an extent that we cannot bring our safety level on par with that of the company.

In brief, careful planning is needed to gain employee as well as business partner support of CSR principles, or else the effectiveness of the approach is bound to suffer.

Legitimacy destruction

The present study reveals that a significant proportion of our respondents fear the threat of legitimacy destruction, as no less than 10 out of 27 interviewees referred to this threat in the conversations we had with them. The following quote derives from the Executive Vice President for Technology, Portfolio, \& Sustainable Development:

O1: Society at large has no specific perception of us at all, but rather a generally negative attitude towards to the sector. In spite of all our HSE efforts, we still haven't managed yet to communicate with society.

Similar concerns about a generally hostile attitude towards the petrochemical industry were voiced during an interview with a New Development Logistics manager:

O9: Another recent example concerns one of our truck drivers, who got into a situation where a car was driving straight toward him on his side of the road. So the driver had to divert, and he himself crashed. In the newspapers the whole thing was reported as 'yet another accident in the petrochemical industry,' whereas the driver essentially did a good thing by not hitting the other car.

In short, even substantial investments in CSR activities do not guarantee a license to operate. 
Especially when companies operate in a contested industry like petrochemicals, tobacco, or weapons manufacturing, no feasible level of CSR investment will ever suffice to shed the negative image that taints these industries by definition (Heugens, 2002).

\section{Issue ownership}

No less than 15 out of our 27 respondents provided evidence for the existence of issue ownership in the sense of heightening rather than lowering societal expectations when making CSR investments. The following illustration was taken from an interview with a group-level Health, Safety, and Environment advisor:

O10: You will always find someone wanting too much. Greenpeace would like us to stop emitting mercury in the air. It is part of a catalyst typically used in oil refineries. In the past, when we did not yet use that catalyst, we emitted a lot more $\mathrm{SO}_{2}$. We have now reduced our $\mathrm{SO}_{2}$ emissions substantively, but we must substitute this with a slightly higher level of mercury emissions. Of course we would also like to reduce our mercury emissions. We do research to begin doing so, but Greenpeace is already complaining.

The dynamics of issue ownership can also be observed from the opposite angle. The following quote was taken from an interview with one of the members of a corporate plant's Neighborhood Council. The council comprises a platform, a company's initiative, in which external stakeholders who live and work in the proximity of a corporate plant participate. Through the council, they can voice their interests and concerns:

O24: One issue that particularly concerns us involves the takeover by foreign firms of plants located on the company's factory grounds. We find it unacceptable when the company says: "that factory is no longer ours, the responsibility for it is out of our hands." That gives us a sneaky feeling.

We: Why does that give you a "sneaky feeling"?
O24: Well, of course those plants will still have to meet the prevailing environmental legislations. But if they [the company] say that the factory is no longer theirs, we worry about whether all provisions will still be met. Are they [the new owners] as good or as bad as the company, is what we then ask ourselves. If they don't comply with the law, then that would be a matter of concern. The neighborhood council would like the company to give stricter guarantees concerning the safety of operations of the plants they sell to outsiders.

Here we see evidence of how a given issue that is no longer a legal responsibility of a firm can still be perceived as a source of societal obligations by the organization's outside publics.

\section{Poor risk communication}

No less than 11 of our 27 interviewees mentioned the risk of creating societal feelings of anxiety due to the adoption of CSR measures, especially when organizations fail to communicate the rationale behind these measures in clear and unambiguous terms. The following illustration derives from an Issues Manager:

We: How is the dialogue with external stakeholders organized, regarding the HSE objectives?

R7: The communication with action groups is rather sparse. And improvement has to come from both sides, the company and activists. I recently saw an e-mail sent by Greenpeace, asking the company to stop working with a list of products that they believe to be dangerous. Yet, their view is completely different from what is accepted in the industry. It actually resembles a conversation between two people, who speak different languages and are deaf to certain sounds!

We: What do external stakeholders expect of the HSE policy of the company?

O7: What they expect is safety, no harm and no negative effects. Well, "expecting" has a double meaning, and this is what they want. [Emphasizes “want”] They basically fear and 
do not trust the chemical industry in general and the company in particular. They see a risk.

We: Are those expectations realistic?

O7: Yes, they are realistic by definition. Even if you would be able to scientifically explain that there is no risk, risk exists in the heads of people. Risk is equal to hazard [Emphasizes "hazard"], which is an engineering measure, and outrage [Emphasizes "outrage"], which is linked to the public's perception of risk. In a group where you have a good dialogue, the outrage is very small. But often there is no dialogue whatsoever, and the outrage is looming around the corner.

One of the specific risks that petrochemical companies must communicate about is "flaring." If the pressure in an oil refinery becomes too high during the refining process, it must release the excess natural gas that emerges as a byproduct during the production of gasoline. Burning the gas in open air typically does this. Flaring is in fact a controlled process, and essentially a safety measure onto itself, but it creates a frightful spectacle (especially at night) and it makes a lot of noise. Without proper risk communication, flaring makes lay people assume that the production process is out of control and arouses feelings of anxiety. The following quote by an environmental technologist comments on this practice:

We: How important is the communication of HSE objectives to external stakeholders?

R16: It is very important, at least to guarantee you your license-to-operate. It impacts your total image, and that in turn helps you recruit the right people and sell your products. Flaring and noise are affecting neighbors, as they always become frightened. Therefore it is important to communicate in advance when you expect to flare, so that they do not have to worry. And the neighbors can also contribute to the improvement of your communication performance, by saying what they think of it.
In sum, CSR investments only have a reputational payoff when they are accompanied by professional communications concerning the risks they are intended to mitigate.

\section{Taming Trojan horses: managerial mitigation strategies}

These two studies illustrate that a variety of organizational and relational risks can emerge from the integration of CSR principles in strategic management. At first glance, the seven risks seem to emerge only when CSR activities are not well managed. For example, risks like diluting managerial attention, bad strategy implementation, and poor risk communication are straightforward references to managerial failure. Upon closer inspection, however, most CSR risks are unexpected side-effects that are imported when CSR activities are adopted. Moreover, these risks were corroborated by a study of an exemplary, highperforming company that is fully committed to its ambitious HSE plans. In other words, even wellmanaged companies expose themselves to risks when CSR measures are implemented.

Unfortunately, CSR risks can have a significant impact on an organization's ability to reach its objectives. Organizational risks can seriously disrupt core organizational transformation processes and hamper the achievement of internal targets and objectives. Likewise, relational risks can erode the organizational license to operate, and damage the organization's reputation and perceived external prestige (cf. Dutton and Dukerich, 1991; Dutton et al., 1994). Since these risks pose a severe threat to corporate competitiveness, we suggest a number of responses that managers can use to tame them.

\section{Mitigating organizational CSR risks}

\section{Diluting managerial attention}

The late Edith Penrose, when commenting on the adoption by corporations of new activities in general, eloquently described the true nature of the risk of diluting managerial attention:

"[I]f a firm deliberately or inadvertently expands its organization more rapidly than the individuals in the 
expanding organization can obtain the experience with each other and with the firm that is necessary for the effective operation of the group, the efficiency of the firm will suffer, even if optimum adjustments are made in the administrative structure; in extreme cases this may lead to such disorganization that the firm will be unable to compete efficiently in the market with other firms, and a period of 'stagnation' may follow", (Penrose, 1959: 47). Seen from a perspective that stresses the experiences that managers have in-house, the problem of reconciling CSR activities with ongoing business practices can be reformulated as to whether or not CSR activities enrich the dynamic capabilities (Eisenhardt and Martin, 2000; Teece et al., 1997) of a particular business. Managers can learn from the demands of stakeholders how their business activities may be improved and what new capabilities the organization may need. This learning process is important, especially since any successful adaptation to the contemporary business environment requires the evaluation and renewal of dynamic capabilities. In short, the problem of diluted managerial attention can be solved when managers only engage in CSR activities that do not stray too far from their companies' current set of dynamic capabilities.

\section{Non-productive spending}

The second risk is associated with the inability of companies to benefit from their investments in CSR activities. Non-productive spending refers to investments that do not improve organizational effectiveness (Khandwalla, 1973). Investments in CSR activities can contribute to the effectiveness of a company directly (for example, when a specific "green" product yields positive discounted cash flows; cf. Porter and van der Linde, 1995) or indirectly (for example, when an organization's efforts to upgrade the working conditions in its suppliers' plants simultaneously improve its corporate reputation; cf. Waddock, 2002). Hence, a broad set of criteria ought to be used to evaluate the contribution of CSR investments to firms' effectiveness.

More specifically, in order to advocate greater prudence, we propose the application of (1) clinical, (2) fiscal, (3) political, and (4) strategic criteria (Meyer, 1984) for the screening of CSR investments. The use of clinical criteria implies the evaluation of a given CSR investment in terms of the benefits it yields for the firm's stakeholders. The use of what Meyer (1984) calls fiscal criteria in the evaluation of CSR activities is perhaps the most intuitive for managers, as it involves a decision of allocating capital based on positive discounted cash flows. The use of political criteria involves an assessment of the extent to which a given investment advances or retards the interests of the organization's dominant coalition (Prahalad and Bettis, 1986). The use of strategic criteria, finally, implies the application of a crude test to establish whether a given CSR investment coheres well with competitors' behavior, demographic trends, and regulatory policies (Meyer, 1984). In a prescriptive sense, these criteria can be seen as a progressive set of screens. We use the notion of progressive screens because neither the dictum that "all four criteria must apply" nor "any one criterion alone is sufficient" seems reasonable. The former alternative is too restrictive, as CSR investments that fail to pass one or two of these screens may sometimes still be deemed attractive. The latter is too forgiving, as CSR investments that fail to pass one or more of the four screens are unlikely to contribute much to organizational effectiveness.

\section{Stretching the organizational coalition}

The third CSR risk refers to broadening the organization's dominant coalition beyond a feasible set. All modern organizations are coalitions of differently endowed and differently motivated parties (Cyert and March, 1963). Such differences can be productive, as they allow for leveraging intraorganizational comparative advantages across internal markets (Jacobides and Croson, 2001). Yet, increasing the diversity of the organizational coalition becomes problematic when the parties involved in the process of decision making become so numerous that consensus becomes difficult or even impossible to obtain. Another problem entails the inability of companies to distribute value to all stakeholders in an enlarged coalition (Clarkson, 1995).

Clearly, managers need to be endowed with authority over residual control rights for various practical reasons (Shleifer and Vishny, 1997). It would be impossible to manage a company if decisions could only be taken after all involved stakeholders have given their approval. Besides, it is logically impossible to satisfy every single stakeholder demand (Jensen, 2001). However, the notion of CSR does not dictate that managers hand over the 
responsibility for taking decisions to their stakeholders, but only that they ought to take into account the interests of as many constituents as possible. Hence, effective CSR management urges managers to integrate the voice of the environment into their decisions (Heugens et al., 2002) without giving up their responsibility to direct the company towards its objectives.

\section{Bad strategy implementation}

The fourth risk associated with CSR investments concerns the problem of bad strategy implementation. The field of strategic management has traditionally harbored strong views as to how corporations should formulate and implement strategic plans (Andrews, 1971; Chandler, 1962; Schendel and Hofer, 1979). Strategy making occurs via a number of interrelated steps, ranging from internal and external analyses through strategy formulation to strategy implementation. The former activities have to do with the creation and prioritization of strategic options, whereas the latter activity denotes the specific actions that allow the organization to realize its targeted priorities (Nutt, 1984). One of the key observations that resulted from our study is that especially this latter task of strategy implementation is often neglected when it comes to CSR activities.

A solution that managers could consider is to treat CSR activities like any other corporate strategy, and use traditional strategy implementation tactics in order to manage them successfully (cf. Bourgeois and Brodwin, 1984). Nutt (1987) has presented a fourfold typology of such tactics, which seems applicable to the problem at hand. Managers can first of all use intervention tactics. These begin by creating a perceived need for CSR involvement in the minds of key decision makers, for example by tying it to desired goals (Dutton et al., 2001). Second, managers may also resort to using participation tactics, which would allow their peers to adapt the CSR proposal by making suggestions and amendments. This tactic creates involvement. Third, persuasion tactics can be adopted, in which case the development of the CSR plan is delegated to an internal or external expert. It is then left up to the expert to develop and present the CSR plan, and to argue for its adoption. Implementation by edict, finally, occurs when managers resort to using their power and authority when implementing CSR plans. This last tactic requires a manager to announce a CSR plan, and prescribe the expected behavior using a memorandum, formal presentation, or on-the-job instruction (Nutt, 1987).

\section{Mitigating relational CSR risks}

\section{Legitimacy destruction}

The first relational risk we identified is that the adoption of CSR activities can be perceived as an act of window dressing by one or several of its external stakeholders, so that the costly activity of choice does not lead to a legitimacy surplus, but in fact to legitimacy destruction. Rather than safeguarding their license to operate, companies may actually risk their societal mandate by engaging in CSR activities, especially if one or several key stakeholders regard these as insincere.

Framed this way, the core question becomes how to establish the sincerity of CSR efforts. The managers of our case study organization were rather keenly aware of the risk of legitimacy destruction, and they had taken a number of related measures to protect their organization against it. First, they formulated so-called "Key Performance Indicators" (KPIs) - quantifiable measures for core organizational processes, established well in advance of a given operational period, that help to evaluate post hoc the organization's CSR performance over that period. KPIs were typically established after substantial stakeholder consultation. Second, they used these KPIs to set the terms of the public debate surrounding the organization's CSR performance by communicating largely in these terms. Third, they sought external endorsement and verification of its performance on these terms, mostly by trustworthy and highly reputed outsiders, in this case two world-renowned auditing firms. This third-person perspective helped to establish the sincerity of the firm's efforts and the effectiveness of its performance. The value of this three-pronged procedure is twofold. On the one hand, the stipulation of KPIs has set goals for the company to reach and be accountable for. On the other, the external verification of the company's social performance helped to alleviate accusations of insincerity and foul play. 


\section{Issue ownership}

Investments in CSR activities generate additional stakeholder expectations with respect to the responsibility of an organization to resolve societal issues (cf. Heugens et al., 2004: 1362). Issue ownership can be particularly frustrating when a company is already contributing with everything it can, and yet is supposed to do even more. This risk is problematic for the competitiveness of organizations in two cases: (1) when issue ownership begins to absorb organizational resource endowments to the extent that companies can no longer invest in the improvement of their organizational effectiveness, and (2) when competitors are systematically adopting a free-rider strategy with respect to this issue.

The first threat implies that a company cannot live up to the increased expectations because this would damage its competitiveness. However, this can be easily perceived as an excuse for unwillingness to invest in the solution of social problems. A solution to such misperceptions could reside in sincere stakeholder involvement, such that corporate constituents are given the opportunity to judge for themselves whether there is willingness on behalf of the organization to solve social problems. In many cases consultations can diminish information asymmetries and initial misperceptions.

The second threat implies that while one organization is investing in a solution to social issues, its competitors gain additional incentives to systematically avoid such investments. Especially large multinational companies tend to end up contributing more than their share, not because smaller companies cannot (proportionately) contribute but rather because of the visibility of multinationals. However, social issues are most effectively solved by means of collective action. The more companies in one industry contribute, the more likely it is that an issue will be resolved. Therefore, the initiation of industry platforms and roundtables can contribute to the effective solution of issues, not just because of their ability to produce concerted action but also because of their contribution to peer-monitoring through the enactment of a jointly perceived "shadow of the future" (Axelrod, 1984).

\section{Poor risk communication}

Finally, organizations can incur lasting damage to their reputations when they do not understand or ignore the perils of poor risk communication (Alsop, 2004). "Risk" refers to the perceived probability of harm in a given situation, as determined by the perceived nature of a given hazard and the perceived extent of one's exposure to that hazard. Risk communication, then, is the process of exchanges about how best to assess and manage such risks among regulatory practitioners, interest groups, the general public, and sometimes academics and opinion leaders (cf. Powell and Leiss, 1997: 33). Professional risk communication adequately informs a public when it is exposed to a given risk, and comforts or soothes a potentially worried audience when no substantial risks exist.

This view on professional risk communication entails that there are two regularly occurring perils. First, a given organization may fail to convey to a certain public that its members are exposing themselves to a risk. Especially when the organization is in such a position that it should be in the knowing, the reputational risk associated with such a lack of communication can be substantial once an organization's audiences eventually do find out that they have been ignored or even misled. Second, due to its communications (or the lack thereof), an organization may arouse certain worries or fears in an audience, when the underlying risk they worry about is in effect very small or even negligible. In the present study, this second peril of risk communication is aptly illustrated by the example of flaring.

How then should companies avoid the perils of risk communication, so that they do not trivialize concrete hazards and simultaneously do not over exaggerate rather mundane risks? One issue on which professional and scholarly opinions converge (Alsop, 2004; Grunig, 1992; Powell and Leiss, 1997) is that organizations should seek continuing connections with their outside audiences on both a rational and an emotional level. At the rational level, it is important to have one's facts straight, to be able to provide clear-cut crisis scenarios, and to communicate about scientific assessments of risk. But issues management battles are seldom decided in the minds of an external audience alone. One must also win or at least speak to - the heart. In less popularizing terms, the corporate message must have a rational as well as an emotional carrier. Regardless of the importance of having a rationally compelling message, it is at least equally important to be able to 
show how a company's CSR attempts contribute to issues or parties that matter to the organization's publics at the emotional level. If a company's loses touch with one or several of its key audiences at either the rational or the emotional level, the likelihood increases that existing risks become trivialized or that non-existing hazards begin to play a significant role in stakeholders' decision-making.

\section{Conclusion}

When urging companies to adopt CSR activities, we also need to advise them about the likely effect of CSR investments on overall business performance. In this paper, we have framed CSR activities as a Trojan horse and identified seven commonly occurring CSR risks, of which four principally play out at the level of the organization and three others at the level of the interorganizational relationship. We urge managers to implement CSR activities with care, and to always use a portfolio of mitigation strategies. Our findings suggest that CSR involvement is not an innocent activity, and that experimenting with it in the hope to contribute to the social good or to gain standing in the eyes of others can be dangerous for the competitiveness of business organizations.

\section{Notes}

1 "E1" denotes "Expert 1." Hence, the quote cited here is derived from an interview with the first expert we interviewed.

2 “O3" denotes "Organization Member 3." Hence, the quote cited here is derived from an interview with the third organization member we interviewed. Note that interviewees 23 to 27 are external stakeholders, so in those cases "O" stands for "Organizational External Stakeholder".

\section{References}

Alsop, R. L.: 2004, The 18 Immutable Laws of Corporate Reputation: Creating, Protecting and Repairing Your Most Valuable Asset (Free press, New York).

Andrews, K. R.: 1971, The Concept of Corporate Strategy (H Dow Jones-Irwin, Homewood).
Ashforth, B. E. and B. W. Gibbs: 1990, 'The DoubleEdge of Organizational Legitimation', Organization Science 1, 177-194.

Axelrod, R. M.: 1984, The Evolution of Cooperation (Basic Books, New York).

Bansal, P.: 2005, 'Evolving Sustainably: A Longitudinal Study of Corporate Sustainable Development', Strategic Management Journal 26, 197-218.

Becker, H. S. and B. Geer: 1960, 'The Analysis of Qualitative Field Data', in R. N. Adams and J. J. Preiss (eds.), Human Organization Research (Dorsey Press, Homewood, IL), pp. 279-289.

Bourgeois, L. J. and D. R. Brodwin: 1984, 'Strategic Implementation: Five Approaches to an Elusive Phenomenon', Strategic Management Journal 5(3), 241-264.

Bowman, E. H. and M. Haire: 1975, 'A Strategic Posture Toward Corporate Social Responsibility', California Management Review XVIII(2), 49-58.

Buysse, K and A. Verbeke: 2003, 'Proactive Environmental Strategies: A Stakeholder Perspective', Strategic Management Journal 24(5), 453-470.

Carroll, A. B.: 1979, 'A Three-Dimensional Conceptual Model of Corporate Performance', Academy of Management Review 4(4), 497-505.

Carroll, A. B. and F. Hoy: 1984, 'Integrating Corporate Social Policy into Strategic Management', Journal of Business Strategy 4(3), 48-57.

Chandler, A. D.: 1962, Strategy and Structure: Chapters in the History of the Industrial Enterprise (MIT Press, Cambridge).

Clarkson, M. B. E.: 1995, 'A Stakeholder Framework for Analyzing and Evaluating Corporate Social Performance', Academy of Management Review 20(1), 92-117.

Coase, R. H.: 1960, 'The Problem of Social Cost', The Journal of Law and Economics III, 1-45.

Cyert, R. M. and J. G. March: 1963, A Behavioral Theory of the Firm (Prentice-Hall, New Jersey).

Daft, R. L. and K. E. Weick: 1984, 'Toward a Model of Organizations as Interpretation Systems', Academy of Management Review 9(2), 284-295.

Dentchev, N. A.: 2004, 'Corporate Social Performance as a Business Strategy', Journal of Business Ethics 55(4), 395-410.

Dentchev, N. A. and A. Heene: 2004, 'Managing the Reputation of Restructuring Corporations: Send the Right Signal to the Right Stakeholder', Journal of Public Affairs 4(1), 56-72.

Dutton, J. E., S. J. Ashford, R. M. O'Neill and K. A. Lawrence: 2001, 'Moves that Matter: Issue Selling and Organizational Change', Academy of Management Journal 44(4), 716-736.

Dutton, J. E. and J. M. Dukerich: 1991, 'Keeping an Eye in the Mirror: Image and Identity in Organizational 
Adaptation', Academy of Management Journal 34, 517-554.

Dutton, J. E., J. M. Dukerich and C. V. Harquail: 1994, 'Organizational Images and Member Identification', Administrative Science Quarterly 39(2), 239-263.

Dutton, J. E. and J. Webster: 1988, 'Patterns of Interest around Issues: The Role of Uncertainty and Feasibility', Academy of Management Journal 31(3), 663-675.

Eisenhardt, K. M. and J. A. Martin: 2000, 'Dynamic Capabilities: What Are They?', Strategic Management Journal 21, 1105-1121.

Fitch, H. G.: 1976, 'Achieving Corporate Social Responsibility', Academy of Management Review 1(1), 38-46.

Flyvbjerg, B.: 2004, 'Five Misunderstandings About Case-Study Research', in C. Seale, G. Gobo, J. Gubrium and D. Silverman (eds.), Qualitative Research Practice (Sage, London), pp. 420-434.

Friedman, M. (1970, Sept. 13). A Friedman Doctrine: The Social Responsibility of Business Is to Increase its Profits. New York Times Magazine.

George, A. L. and A. Bennett: 2004, Case Studies and Theory Development (MIT Press, Cambridge, MA).

Gerring, J.: 2004, 'What Is a Case Study and What Is it Good for?', American Political Science Review 98(2), 341354.

Glaser, B. G. and A. L. Strauss: 1967, The Discovery of Grounded Theory: Strategies for Qualitative Research (Weidenfeld and Nicholson, London).

Grunig J. E. (Ed.) (1992) Excellence in Public Relations and Communication Management. (Mahwah: Lawrence Erlbaum Associates, Inc.).

Hertz, N.: 2001, The Silent Takeover: Global Capitalism and the Death of Democracy (William Heinemann, London).

Heugens, P. P. M. A. R.: 2002, 'Strategic Issues Management: Implications for Corporate Performance', Business \& Society 41(4), 456-468.

Heugens, P. P. M. A. R.: 2005, 'Issues Management: Core Understandings and Scholarly Development', in P. Harris and C. Fleisher (eds.), The Handbook of Public Affairs (Sage, London), pp. 481-500.

Heugens, P. P. M. A. R., K. Lamertz and L. Calmet: 2003, 'Strategic Groups and Corporate Citizenship: Evidence from the Canadian Brewing Industry', Journal of Corporate Citizenship 3(12), 75-92.

Heugens, P. P. M. A. R., F. A. J. van den Bosch and C. B. M. van Riel : 2002, 'Stakeholder Integration: Building Mutually Enforcing Relationships', Business E Society 41(1), 36-60.

Heugens, P. P. M. A. R. and J. van Oosterhout : 2002, 'The Confines of Stakeholder Management: Evidence from the Dutch Manufacturing Sector', Journal of Business Ethics 40(4), 387-403.
Heugens, P. P. M. A. R., C. B. M. van Riel and F. A. J. van den Bosch : 2004, 'Reputation Management Capabilities as Decision Rules', Journal of Management Studies 41(8), 1349-1377.

Hosmer, L. T.: 1994, 'Strategic Planning as if Ethics Mattered', Strategic Management Journal 15, 17-34.

Husted, B.: 2000, 'A Contingency Theory of Corporate Social Performance', Business \& Society 39(1), 24-48.

Husted, B. W. and D. B. Allen: 2000, 'Is it Ethical to Use Ethics as Strategy', Journal of Business Ethics 27(1/2), 21-31.

Husted B. W., Allen D. B. (2004) Strategic Corporate Social Responsibility and Value Creation among Large Firms in Spain. Paper Presented at the Fifteenth Annual Meeting of the International Association for Business and Society, 4-7 March, Jackson Hole, WY, USA.

Jacobides, M. G. and D. C. Croson: 2001, 'Information Policy: Shaping the Value of Agency Relationships', Academy of Management Review 26(2), 202-223.

Jensen, M. C.: 2001, 'Value Maximization, Stakeholder Theory, and the Corporate Objective Function', European Financial Management 7(3), 279-317.

Keim G. D. (1978) Corporate Social Responsibility: An Assessment of the Enlightened Self-Interest Model. Academy of Management Review, 32-39.

Khandwalla, P. N.: 1973, 'Viable and Effective Organizational Designs of Firms', Academy of Management Journal 16(3), 480-494.

Lantos, G. P.: 2001, 'The Boundaries of Strategic Corporate Social Responsibility', Journal of Consumer Marketing 18(7), 595-630.

Lincoln, Y. S. and E. G. Guba: 1985, Naturalistic Inquiry (Sage, Newbury Park, CA).

Margolis, J. D. and J. P. Walsh: 2001, People and Profits? The Search for a Link Between Company's Social and Financial Performance (Mahwah, New Jersey).

Margolis, J. D. and J. P. Walsh: 2003, 'Misery Loves Companies: Rethinking Social Initiatives by Business', Administrative Science Quarterly 48, 268-305.

McWilliams, A. and D. Siegel: 2001, 'Corporate Social Responsibility: A Theory of the Firm Perspective', Academy of Management Review 26(1), 117-127.

Meyer, A. D.: 1984, 'Mingling Decision Making Metaphors', Academy of Management Review 9(1), 6-17.

Nutt, P. C.: 1984, 'A Strategic Planning Network for Non-Profit Organizations', Strategic Management Journal 5(1), 57-75.

Nutt, P. C.: 1987, 'Identifying and Appraising how Managers Install Strategy', Strategic Management Journal 8(1), 1-13.

Penrose, E.: 1959, The Theory of the Growth of the Firm (Basil Blackwell, London). 
Porter, M. E.: 1980, Competitive Strategy: Techniques for Analyzing Industries and Competitors (The Free Press, New York).

Porter, M. E. and C. v. d. Linde: 1995, 'Green and Competitive: Ending the Stalemate', Harvard Business Review 73(5), 120-134.

Powell, D. and W. Leiss: 1997, Mad Cows and Mother's Milk: The Perils of Poor Risk Communication (McGillQueen's University Press, Montreal).

Prahalad, C. K. and R. A. Bettis: 1986, 'The Dominant Logic: A New Linkage Between Diversity and Performance', Strategic Management Journal 7, 485-501.

Prahalad, C. K. and R. A. Bettis: 1995, 'The Dominant Logic: Retrospective and Extension', Strategic Management Journal 16, 5-14.

Przeworski, A. and H. Teune: 1970, The Logic of Comparative Social Inquiry (Robert E. Krieger, Malabar, FL).

Rugman, A. M. and A. Verbeke: 1998, 'Corporate Strategies and Environmental Regulations: An Organizing Framework', Strategic Management Journal 19, 363-375.

Schendel, D. E. and C. W. Hofer: 1979, Strategic Management: A New View of Business Policy and Planning (Little, Brown, Boston).

Shleifer, A. and R. W. Vishny: 1997, 'A Survey of Corporate Governance', Journal of Finance 52(2), 737-783.

Starik, M. and A. Marcus: 2000, 'Introduction to the Special Research Forum on the Management of Organizations in the Natural Environment: A Field Emerging from Multiple Paths, with Many Challenges Ahead', Academy of Management Journal 43(4), 539-546.

Stevens, J. M., H. K. Steensma, D. A. Harrison and P. L. Cochran: 2005, 'Symbolic or Substantive
Document? The Influence of Ethics Codes on Financial Executives' Decisions', Strategic Management Journal 26, 181-195.

Teece, D. J., G. Pisano and A. Shuen: 1997, 'Dynamic Capabilities and Strategic Management', Strategic Management Journal 18(7), 509-533.

Waddock, S. A.: 2002, Leading Corporate Citizens: Vision, Values, Value Added (McGraw-Hill, Boston).

Waddock, S. A. and S. B. Graves: 1997, 'The Corporate Social Performance - Financial Performance Link', Strategic Management Journal 18(4), 303-319.

Wartick, S. L. and P. L. Cochran: 1985, 'The Evolution of the Corporate Social Performance Model', Academy of Management Review 10(4), 758-769.

Wells, C.: (1998), Corporate Responsibility. Encyclopedia of Applied Ethics, 1.

Yin, R. K.: (1994), Case Study Research: Design and Methods (2nd ed. Vol. 5). (Sage Publications, London).

Pursey Heugens

Business-Society Management, RSM Erasmus University, PO Box 1738, Rotterdam, 3000 DR, The Netherlands E-mail:pheugens@rsm.nl

Nikolay Dentchev

Department of Management and Entrepreneurship, Ghent University, 24 Hoveniersberg, Ghent 9000, Belgium 